\title{
KONTRIBUSI ILMUWAN MUSLIM DALAM PERKEMBANGAN SAINS MODERN
}

\author{
Imam Amrusi Jailani \\ Universitas Islam Negeri Sunan Ampel Surabaya \\ e-mail: sriamrusi@yahoo.co.id
}

\begin{abstract}
This paper presents a discussion of the contribution of muslim scientists to the development of modern science. It is well known that in the golden ages of Islam many scientists are very competent in their respective fields emerging. They succeeded in emerging as philosophers and scientists capable of filling various fields of science, such as medicine, mathematics, chemistry, physics, and so forth others. Their scholarship is valuable especially for the development of science in the future. So precious their scholarship and what they dedicated, so not infrequently the scientists who come later dub them as the father of science in their respective fields. However, not all of them will be discussed in this paper, but only the triumvirate of muslim scientists, namely Ibn Rushd, Ibn al-Haytham, dan Jabir ibn Hayyan. Their contribution is so great to the development of modern science and is recognized by scientists both in the East, and especially in the West.
\end{abstract}

\begin{abstract}
Abstrak: Tulisan ini menyuguhkan pembahasan mengenai kontribusi ilmuwanilmuwan muslim bagi perkembangan sains modern. Sudah jamak diketahui bahwa pada zaman keemasan Islam banyak bermunculan ilmuwan yang sangat kompeten di bidangnya masing-masing. Mereka berhasil tampil sebagai filosof dan saintis yang mengisi berbagai bidang keilmuwan, seperti kedokteran, matematika, kimia, fisika dan sebagainya. Keilmuwan mereka sangat berharga terutama bagi perkembangan sains pada masa-masa berikutnya. Begitu berharganya keilmuwan dan apa yang dipersembahkan oleh mereka, sehingga tidak jarang para ilmuwan yang datang belakangan menjuluki mereka sebagai bapak sains di bidangnya masing-masing. Namun, tidak semua dari mereka akan dibahas dalam tulisan ini, melainkan hanya triumvirat ilmuwan muslim, yakni Ibn Rushd, Ibn al-Haytham, dan Jabir ibn Hayyan. Kontribusi ketiganya begitu besar bagi perkembangan sains modern dan diakui kalangan saintis, baik di Timur dan khususnya di Barat.
\end{abstract}

Keywords: Islam; science; modern; contribution

\section{A. Pendahuluan}

Islam memberikan apresiasi yang amat tinggi terhadap akal. Demikian tingginya sehingga akal menempati posisi yang urgen dan vital dalam pergumulan wacana keislaman. Oleh karena itu, akal sering kali disandingkan dengan wahyu dalam banyak kesempatan dan pembahasan. Dengan demikian, 
maka wajarlah jika dikatakan bahwa Islam sangat menghargai ilmu pengetahuan. Tentu saja produk dari pendayagunaan akal adalah ilmu pengetahuan. Dari akal dan daya pikir yang telah dianugerahkan oleh Allah, manusia dapat menggali berbagai pengetahuan yang ada di alam semesta, baik yang bersifat makro maupun mikro. Dengan demikian munculllah berbagai disiplin ilmu. ${ }^{1}$

Hal ini dalam sejarah Islam dibuktikan dengan maraknya perkembangan ilmu dari berbagai bidang dan munculnya ratusan bahkan ribuan sarjanasarjana Muslim. Penghargaan Islam terhadap akal dan ilmu pengetahuan bukan hanya basa-basi, karena hal itu telah dilaksanakan dan dipraktekkan oleh para ulama, atau kaum terpelajar Islam, yang luar biasa jumlahnya. Keadaan yang kondusif seperti itu telah berhasil menampilkan beberapa filosof muslim terkemuka, seperti al-Kindī (801-873 M), al-Farabī (870-950 M), al-Rāzī (864$930 \mathrm{M}$ atau 251-313 H), Ibn Tufail (1105-1185 M), Ibn Bajjah (1085-1138 M), dan sejumlah pakar pada bidangknya masing-masing, seperti Ibn Rushd (11261198 M), Ibn al-Haytham (965-1040 M atau 354-430 H), dan Jabir ibn Hayyan (721-815 M) serta pakar etika muslim, Ibn Maskawaih (932-1030 M atau 330 $421 \mathrm{H})^{2}$

Sebenarnya banyak sekali sarjana-sarjana muslim yang tampil dalam panggung sejarah. Dalam kitab Uyūn al-Anbä' fi Tabaqat al-Ațibba' karangan Ibn Abi Ushaybi'ah, seorang ahli kedokteran abad ketiga belas, dimuat informasi dan biografi lebih dari tiga ratus lima puluh ilmuwan muslim. Ada ahli kedokteran, ahli kimia, geometri, geologi, geografi, matematika, astronomi dan sebagainya. Padahal yang dikenal masih segelintir saja. Hanya sayangnya, karena sistem pendidikan kita masih bercermin dan berkiblat ke Barat, sedangkan Barat menyembunyikan jasa-jasa Islam dalam arena ilmu pengetahuan, maka publik pada dasarnya tidak mengenal tokoh-tokoh Islam yang sebenarnya sangat besar dan terkenal. Padahal perkembangan dan kemajuan ilmu pengetahuan di Barat merupakan imbas dan terpengaruh oleh kemajuan yang terjadi di dunia Islam,

${ }^{1}$ Siti Romlah, "Sains dan Teknologi dalam al-Qur'an: Fenomena Makrokosmos dan Mikrokosmos," Jurnal Studi Islam: Pancawacana 11, No. 2 (Desember 2016), 2.

${ }^{2}$ Beliau adalah Abū 'Alī Aḥmad bin Muhammad Miskawaih. Pikiran-pikirannya dapat dilihat dalam Muhammad Yūsuf Mūsā, Falsafat al-Akhlāq al-Islām (Kairo: Mu'assasah al-Khārijī al'Arabiyyah, 1963), 73 dst:; Țawīl Tawfiq, Falsafat al-Akhlāq: Nash'atuh wa Tațawwuruh (Kairo: Nahdhat al-'Arabiyyah, 1979), 162 dst; Ahmad Muhammad Shubhī, al-Falsafat al-Akhlāqiyyah fi alFikr al-Islāmī (Mesir: Dār al-Ma’ārif, 1969); D.L. Donaldzen, Studies in Muslim Ethics (London: t.p., 1953), 123 dst. 
terutama setelah adanya gerakan Averroisme ${ }^{3}$ yang membumi di Eropa. Barat mendapatkan pengaruh positif dalam ilmu pengetahuan dari dunia Islam.

\section{B. Pengaruh Averroisme terhadap Pencerahan Pendidikan Islam}

Pikiran-pikiran Ibn Rushd telah berhasil membuka cakrawala baru bagi dunia ilmu pengetahuan. Eksplorasi Ibn Rushd terhadap dunia ini telah mengundang animo besar-besaran bagi kalangan pelajar dan sarjana, baik di dunia Islam maupun Barat, untuk mentransfer pikiran-pikirannya. Transformasi pandangan-pandangan Ibn Rushd dapat diakses melalui karya-karyanya dan perkuliahan di berbagai universitas, di antaranya Universitas Cordoba, Sevilla, Malaga, Granada, dan Samalanca, di Andalusia. Para pelajar dari Eropa berduyunduyun untuk menimba ilmu di institusi-institusi tersebut. Kemudian mereka mengusung pola pikir Ibn Rushd ke dataran Eropa, seperti di Universitas Padua, Bologna, Ferrara, dan Venice di Italia. Bahkan menurut Ernest Renan (1823-1892 M), karya-karya beliau diterjemahkan dan dicetak berulang-ulang di Eropa dan Latin. ${ }^{4}$ Di Universitas Paris, Prancis, tidak kalah hebatnya, yakni mendatangkan tenaga edukasi secara khusus dari Andalusia untuk mengajarkan pola pikir Averroes. ${ }^{5}$ Di universitas tersebut terdapat seorang guru besar yang membidangi komentar-komentar Ibn Rushd, yaitu Siger de Brabant (1240-1280 M).

Sejarawan Eropa mengenangnya sebagai 'jembatan pengetahuan' antara Timur dan Barat, penghubung antara Islam dan Kristen dom. Dialah Ibnu Rushd atau Averroes, tokoh yang disebut-sebut sebagai printis gerakan pencerahan di Barat, idola baru kaum liberalis di Eropa. Setelah beberapa abad kiprahnya terkubur oleh limbo sejarah, sosok Ibnu Rushd seolah-olah hidup kembali. Adalah Ernest Renan —-menurut Dr. Syamsuddin Arif (peneliti INSISTS) — yang pertama kali mengungkit semula ketokohan beliau lewat karyanya "Averroesetl'

\footnotetext{
${ }^{3}$ Averroisme merupakan sebuah gerakan pemikiran yang berupaya menghidupkan kembali gagasan-gagasan Ibn Rushd, yang memiliki nama lengkap al-Qāḍi Abū al-Walīd Muhammad bin Ahmad bin Muhammad bin Rushd. Debutnya dalam dunia filsafat dapat dilihat dalam Muhammad Yūsuf Mūsā, Bain al-Dīn wa 'l-Falsafah fi Ra'yi Ibn Rushd wa Falasifah fi 'Ashr al-Wāsit (Mesir: Dār alMa'ārif, t.th.), dan al-Nash'at al-'Aqliyyah fi Falsafah Ibn Rushd (Mesir: Dār al-Ma'ārif, t.th.); Oliver Leaman, Averroes and his Philosophy (Oxford: Clarendon Press, 1988) dan Mahmūd Qāsim, Falsafah Ibn Rushd wa Atsaruha fi al-Tafkīr al-Garbī (Kairo: Jāmi’ah Umm al-Qarmān al-Islāmiyyah, 1967).

${ }^{4}$ Lihat Zainal Abidin Ahmad, Riwayat Hidup Ibn Rusyd (Averroes): Filosof Islam Terbesar di Barat (Jakarta: Bulan Bintang, 1975), 151.

5Philip K. Hitti, History of The Arabs (London: Macmillan, 1970), 555.
} 
Averroisme". Menurut intelektual Prancis berdarah Yahudi itu, Ibnu Rushd adalah peletak batu pertama rasionalisme Eropa. Dengan fasih diceritakannya riwayat hidup Ibnu Rushd serta nasib akhir warisan pemikirannya di dunia Islam dan Eropa. Karya Renan telah menjadi obat penawar duka. Dengan membacanya, maka para pembaca seolah-olah menemukan pusaka yang hilang. ${ }^{6}$

Sarjana pertama yang ditengarahi mengusung pikiran Ibn Rushd ke dunia Latin adalah Michael Scott, yang pada tahun 1230 M. menerjemahkan karyanya Commentary of the Sky and the Nature (komentar tentang langit dan alam) dan Commentary of the Soul (komentar tentang jiwa). Kemudian Hermann dari Jerman menerjemahkan buku Kulliyat, Colliget. $^{7}$ Gerakan Averroisme telah menancapkan pengaruh yang amat kuat di Barat hingga mampu menggulung doktrin Theologia Kristen Ortodok dan Augustinisme di zaman Skolastik, yang pada akhirnya melahirkan gerakan Renaissance.

Renaissnce berarti kelahiran kembali, yakni upaya untuk menghidupkan kembali kebudayaan klasik Yunani dan Romawi. Zaman Renaissance sering disebut pula zaman Humanisme, ${ }^{8}$ yakni zaman di mana manusia diangkat dari zaman pertengahan. Ciri khas yang melekat pada zaman ini adalah humanisme, individualisme, lepas dari agama, empirisme, dan rasionalisme. ${ }^{9}$ Di zaman ini pandangan-pandangan Ibn Rushd sangat digandrungi, baik yang ditanformasikan lewat karya-karyanya maupun melalui komentar-komentar para muridnya.

Mengenai masalah kebenaran, Ibn Rushd percaya pada apa yang disebut "kesatuaan seluruh kebenaran," yang merupakan satu-satunya cara di mana para filosof Muslim bila menjustifikasi pemburuan filosofis mereka, meredakan amarah para teologis, dan memuaskan hasrat pikiran oleh koherensi internal."10 Akibatnya, kebenaran filosofis yang dicapai melalui penyelidikan rasional pada dasarnya sama dengan kebenaran agama yang didasarakan pada wahyu Ilahi. "Ibn Rushd," demikian Mahdi berkata, " menafsirkan identitas hukum Ilahi dan

${ }^{6}$ Syamsuddin Arif, "Ibnu Rusyd dan Kemajuan Barat", dalam Islamia: Jurnal Pemikiran Islam Republika, edisi Kamis, 20 Januari 2011.

${ }^{7}$ Ahmad, Riwayat Hidup Ibn Rusyd, 146.

${ }^{8}$ Lihat Poedjawijatna, Pembimbing ke Arah Filsafat (Jakarta: Rineha Cipta, 1994), 98-99.

${ }^{9}$ Lihat Ahmad Tafsir, Filsafat Umum: Akal dan Hati Sejak Thales sampai James (Bandung: PT. Remaja Rosdakarya, 1990), 109-111.

${ }^{10}$ Madjid Fakhry, A Histoty of Islamic Philosophy (New York London: Columbia University Press, and Longman, 1983), 277. 
filsafat manusiawi untuk maksud identitas hukum Ilahi dan filsafat manusia melalui tujuan mereka,"11 yaitu "berusaha untuk mendapatkan kebahagiaan dan kebenaran."12 Dalam kitabnya Fashl al-Maqal, Ibn Rushd mengatakan: "jika syariah adalah suatu kebenaran dan anjuran untuk menyelidiki (segala yang ada) yang mengarah pada pengetahuan tentang kebenaran tersebut, maka umat Islam akan mengetahui dengan pasti bahwa penyelidikan demostratif tidak akan menciptakan kontradiksi apapun dengan apa yang syariah nyatakan, karena kebenaran tidak akan pernah bertentangan dengan kebenaran, tetapi satu sama lainnya saling menjadi saksi." ${ }^{\text {13 }}$

Selain Ibn Rushd, masih banyak ilmuwan muslim yang berkiprah di bidang sains dengan keahliannya masing-masing dan memiliki pengaruh yang sangat besar bagi pertumbuhan dan perkembangan sains itu sendiri. Di antara mereka adalah Ibn al-Haytham dan Jabir ibn Hayyan. Berikut ini akan dikemukakan pemikiran-pemikiran mereka berdua dan pengaruhnya terhadap perkembangan sains modern, terutama di bidang keahlian mereka masing-masing.

\section{Pemikiran Ibn al-Haytham}

Ibn al-Haytham dilahirkan di Basrah pada tahun $354 \mathrm{H}$ bertepatan dengan 965 M. Ia memulai pendidikan awalnya di Basrah. Setelah itu beliau mengabdi menjadi pegawai pemerintah di daerah kelahirannya. Setelah beberapa lama berbakti kepada pihak pemerintah di sana, beliau mengambil keputusan merantau ke Ahwaz dan Baghdad. Di perantauan beliau melanjutkan pendidikan dan mencurahkan perhatian pada penulisan. Kecintaannya kepada ilmu telah membawanya berhijrah ke Mesir. Selama di sana beliau mengambil kesempatan melakukan beberapa kerja penyelidikan mengenai aliran Sungai Nil serta menyalin buku-buku mengenai matematika dan falak. Tujuannya adalah untuk mendapatkan uang tambahan dalam menempuh perjalanan menuju Universitas al-Azhar. Usaha itu membuahkan hasil, beliau menjadi seorang yang amat mahir dalam bidang sains, falak, matematika, geometri, pengobatan, dan falsafah.

\footnotetext{
11Lihat Muhsin Mahdi dalam M.E. Marmura (ed.) Islamic Teology and Philosophy , (Albany: State University of New York Press, 1984), 192.

${ }^{12}$ Oliver Leaman, An Introduntion to Medieval Islamic Philosophy, (Cambridge: Cambridge University Press, 1985), 170.

13Ibn Rushd, "Fașl al-Maqal fi mā bayna al-Hiikmah wa al-Shari'ah", dalam Kitab Falsafah Ibn Rushd (tanpa data), 7.
} 
Tulisannya mengenai mata, menjadi salah satu rujukan yang penting dalam bidang pengembangan sains di Barat.

Ibn al-Haytham merupakan ilmuwan yang gemar melakukan penyelidikan. Penyelidikannya mengenai cahaya telah memberikan ilham kepada ahli sains Barat seperti Boger Bacon, dan Kepler, pencipta mikroskop serta teleskop. Ia merupakan orang pertama yang menulis dan menemukan berbagai data penting mengenai cahaya.

Beberapa buah buku mengenai cahaya yang ditulisnya telah diterjemahkan ke dalam bahasa inggris, antara lain Light on Twilight Phenomena. Kajiannya banyak membahas mengenai senja dan banyak lingkaran cahaya di sekitar bulan dan matahari serta bayang-bayang dan gerhana.

Beberapa percobaan dilakukan oleh Ibn al-Haytham, di antaranya percobaan terhadap kaca yang dibakar, dan dari situ ditemukanlah teori lensa pembesar. Teori itu telah digunakan oleh para ilmuwan di Itali untuk menghasilkan kaca pembesar yang pertama di dunia dan prinsipnya tetap diadopsi oleh ilmuwan-ilmuwan setelahnya.

Demikian pula dengan prinsip padu udara yang ternyata lebih menakjubkan, Ibn al-Haytham telah menemukan dan memperkenalkannya jauh sebelum seorang ilmuwan yang bernama Tricella yang mengetahui masalah itu 500 tahun kemudian. Ibn al-Haytham juga disinyalir telah menyampaikan keberadaan gaya tarik bumi atau gravitasi sebelum Issaac Newton mengetahuinya. Selain itu, teori Ibn al-Haytham mengenai jiwa manusia sebagai satu rentetan perasaan yang bersambung-sambung secara teratur telah memberikan ilhan kepada ilmuwan Barat untuk menghasilkan wayang gambar. Teori beliau telah membawa kepada penemuan film yang kemudian disambung-sambung dan dimainkan kepada para penonton sebagaimana yang dapat kita lihat pada masa kini.

Ibn al-Haytham meninggal di Kairo, Mesir, sekitar tahun 1040 M. Karena pengamatannya yang mendalam pada bidang optika, konsep-konsepnya menjadi dasar ilmu optika. Selain itu, dia mengantarkan optika pada kemajuan pesat masa kini. Dengan demikian, Ibn al-Haytham mendapat julukan sebagai "Bapak Optika Modern." ${ }^{4}$

${ }^{14}$ Mohamed Mohaini, Matematikawan Muslim Terkemuka (Jakarta: Salemba Teknika, 2004). 


\section{Teori Penglihatan (Optik)}

Dengan menggunakan kaedah matematika dan fisika modern yang baik, beliau dapat membuat eksperimen yang teliti. Ibnu al-Haytham telah meletakkan prinsip-prinsip optik pada asas yang kokoh. Beliau menggabungkan teori dan eksperimen dalam penelitiannya. Dalam penyelidikannya, beliau telah mengkaji gerakan cahaya, ciri-ciri bayang dan gambar, serta banyak lagi fenomena optik yang penting. Beliau menolak teori Ptolomy dan Euclid yang mengatakan bahwa manusia melihat benda melalui pancaran cahaya yang keluar dari matanya. Tetapi menurut Ibnu al-Haytham, bukan mata yang memberikan cahaya tetapi benda yang dilihat itulah yang memantulkan cahaya ke mata manusia.

\section{Cermin Kanta Cekung dan Kanta Cembung}

Ibnu al-Haytham telah menggunakan mesin lathe (larik) untuk membuat cermin kanta cekung dan kanta cembung untuk penyelidikannya. Dengan ini beliau telah mengkaji tentang cermin sfera dan cermin parabolik. Beliau mengkaji aberasi sferis dan memahami bahwa dalam cermin parabola ke semua cahaya dapat tertumpu pada satu titik.

\section{Teori Biasan Cahaya}

Teori ini agak mengagumkan, beliau telah menggunakan segi empat roadmap pada permukaan biasan beberapa abad sebelum Isaac Newton memperkenalkannya di dunia Barat. Beliau juga percaya kepada prinsip masa tersingkat bagi rentasan cahaya (prinsip fermat). ${ }^{15}$

\section{Karya Ibnu Haytham tentang Optik}

Ibn Haytham merupakan seorang sarjana muslim yang terkenal di dunia Islam dan juga terkenal di kalangan sarjana Barat, yang dikenal di sana dengan nama Alhazen (965-1039 M). Karya-karyanya tidak kurang dari dua ratus buah, yang meliputi matematika, fisika, astronomi, kedokteran dan optik, serta karyakarya terjemahan atau komentar atas karya filsafat Aristoteles dan Galen. Karya monomentalnya adalah di bidang optik, yaitu al-Manāzir, yang membahas

15Jamil Ahmad, Seratus Muslim Terkemuka (Jakarta: Pustaka Firdaus, t.th.), 183-184. 
mengenai masalah-masalah yang berkaitan dengan mata. Karya tersebut merupakan refleksi dari kinerja eksperimental yang sudah dibangunnya. Kinerja ilmiah yang sudah dibangun oleh beliau ditransfer oleh Roger Bacon, yang dipandang di Barat sebagai bapak dari metode eksperimental. Al-Manāzirir ini juga diterjemahkan ke dalam bahasa Latin, Opticae Thesaurus, dan diterbitkan di Barat pada abad ke-16, dan karya ini juga amat berpengaruh terhadap Kepler di bidang optik.

Al-Manāzir adalah satu dari karya Ibn al-Haytham yang teragung tentang bidang kajian optik dan buku tersebut pernah menjadi rujukan bagi para ahli kajian optik setelahnya. Karya ini diterjemahkan oleh Witelo pada tahun $1270 \mathrm{M}$ dan kemudian diterbitkan oleh F. Risner pada tahun 1572M dengan nama Thesaurus Opticae. ${ }^{16}$

Dalam literatur lain dijumpai bahwa kitab al-Manāzirir telah diterjemahkan ke dalam bahasa Latin dengan judul Opticae Thesaurus Alhazeni Arabis, yang disebarkan oleh Fried Risner pada tahun 1572 dengan libri septem nunc primum editi. ${ }^{17}$

\section{Relevansi Teori Ibn al-Haytham dengan Sains Masa Kini}

Pemikiran Ibn al-Haytham mengenai optik telah banyak memberikan pengaruh kepada ilmuwan-ilmuwan Barat, hal ini terjadi setelah diterjemahkannya karya-karya Ibn al-Haytham ke dalam bahasa Latin. Pada abad ke-13 M, sarjana Inggris, Roger Bacon (1214-1294 M), menulis tentang kaca pembesar dan menjelaskan bagaimana membesarkan benda menggunakan sepotong kaca. "Untuk alasan ini, alat-alat ini sangat bermanfaat untuk orang-orang tua dan orang-orang yang memiliki kelemahan pada penglihatan, alat ini disediakan untuk mereka agar bisa melihat benda yang kecil, jika itu cukup diperbesar," jelas Roger Bacon.

Beberapa sejarawan ilmu pengetahuan menyebutkan Bacon telah mengadopsi ilmu pengetahuannya dari Ibn al-Haytham. Bacon terpengaruh dengan

16Syarach Meirizka, Sang Jenius Optik "The True Scientist" Ibnu Al-Haytham (email version), Scientia Experia Publisher, 2011

${ }^{17}$ Lihat penjelasan selengkapnya dalam Abdurrahman, Pengaruh Arab dalam Bentuk Pemikiran Eropa (Suatu Catatan Kebangkitan Islam), terj. Mohammad Ma'ruf Misbah (Semarang: CV. Wicaksana, t.th.), $27-28$. 
kitab yang ditulis al-Haytham berjudul Kitab al-Manāzir. ${ }^{18}$ David L. Shenkenberg menulis sebuah artikel yang berjudul, "Before Newton, there was Alhazen".

Jika dibaca semua karya Alhazen, Roger Bacon dari abad ke-14 dan Sir Isaac Newton, mungkin disadari bahwa banyak hal yang dikaitkan dengan Sir Isaac Newton ternyata adalah milik Alhazen. Paradigma dari dua peradaban, yang timbul dari politik Perang Salib, menghapuskan nama Alhazen atas penghargaan ini. Sekaranglah saat yang tepat untuk memulai studi tentang karya-karya mereka yang hebat ini, yang saling melengkapi untuk memiliki pemahaman yang lebih baik tentang sejarah ilmu pengetahuan.

Alhazen juga menjelaskan pembiasan dan dispersi cahaya ke dalam beberapa komponen warna. Gagasan ini juga pernah dicetuskan oleh Isaac Newton. "Tentu saja di bidang optik, Newton sendiri hidup 700 tahun setelahnya," kata Jim al-Khalili, seorang profesor fisika di University of Surrey di Inggris. Peraih nobel dalam bidang fisika, Dr. Abdus Salam juga menulis:

"Ibn al-Haytham (Alhazen, 965-1039 M) adalah salah satu fisikawan terbaik sepanjang masa. Dia melakukan kontribusi eksperimental dari tingkat tertinggi di bidang optik. Dia mengungkapkan bahwa seberkas cahaya, dalam melewati media, mengambil jalan yang lebih mudah dan 'lebih cepat'. Dalam hal ini ia mengadaptasi Prinsip Fermat. Dia juga menyatakan hukum inersia, yang akhirnya menjadi hukum pertama Newton tentang gerak."

\section{Ibn al-Haytham Membawa Pengaruh ke Dunia Barat}

Ibnu al-Haytham adalah ilmuwan muslim yang mengkaji ilmu optik dengan kualitas riset yang tinggi dan sistematis. Menurut Howard R Turner, dalam karyanya "Science in Medieval Islam", sebagaimana dikutip oleh Fauziah, dalam Kompasiana ${ }^{19}$, ilmu optik merupakan penemuan yang paling orisinil dan penting dalam sejarah Islam.

\footnotetext{
18Fauziah, "Rahasia Dibalik Penemuan Kacamata", dari http://www.republika.co.id/berita/ ensiklopedia-islam/khazanah/09/04/30/47404-rahasia-di-balik-penemuan-kacamata.html, diakses pada 26 Mei 2012.

${ }^{19}$ Fauziah, "Ibnu al-Haitsam: Sejarah Penemuan Optik dan Pengaruhnya terhadap Sains Barat Modern", dalam Kompasiana, edisi 28 Desember 2012. http://sejarah.kompasiana.com/ 2012/12/29/ibnu-al-haitsam-sejarah-penemuan-optik-dan-pengaruhnya-terhadap-sains-baratmodern-.html\#_ftn19, diakses pada 14 Juni 2014.
} 
Sigrid Hunke menjelaskan, al-Hasan bin al-Haytham adalah salah seorang ilmuwan Arab yang mengajar di dunia Barat serta paling banyak berperan dan berpengaruh. Dia seorang yang brilian dan pengaruh keilmuwannya di negara Barat luar biasa. Teori-teorinya di dua bidang disiplin ilmu kimia dan ilmu optik (Opus Mains), telah mewarnai ilmu-ilmu pengetahuan di Eropa sampai sekarang ini. Berpijak dari dasar-dasar dalam kitab al-Manāzir karya Ibnu al-Haytham, setiap yang berkaitan dengan ilmu optik mulai berkembang, berawal dari Inggris (Ruggero Bacone) sampai di Jerman (Witelo). Adapun Leonardo da Vinci, seorang ilmuwan berkebangsaan Italia yang menemukan alat (foto rontgen) atau penggelap, penemu semprotan air, mesin bubut, dan manusia pertama yang dapat terbang -menurut klaimnya- maka secara tidak langsung dia telah dipengaruhi oleh kaum Muslimin dan banyak terinspirasi oleh pemikiranpemikiran al-Haytham. Tatkala Kepler dari Jerman sekitar abad ke-16 meneliti hukum-hukum yang digunakan sandaran Galileo untuk melihat bintang yang tidak terlihat melalui teropong besar, maka nama besar Ibnu al-Haytham senantiasa membayang-bayangi di belakangnya. Bahkan sampai masa kita sekarang ini, masalah fisika dan matematika yang sangat sulit ini berhasil dipecahkan oleh Ibnu al-Haytham melalui pantulan benda segi empat, yang menjelaskan tentang betapa cemerlang dan cermatnya Ibnu al-Haytham dalam bidang ilmu Aljabar. Kita katakan bahwa permasalahan seputar letak titik fokus yang dipantulkan cermin yang terkena cahaya menyebar di daerah jarak pantulnya senantiasa disebut masalah "Haythamiyah", dinisbatkan kepada Ibnu al-Haytham sendiri.

Menurut Sigrid Huke pula, orang-orang muslim Arab telah mengembangkan bahan-bahan mentah yang diperoleh dari Yunani (Greek) dengan uji coba dan penelitian ilmiah, kemudian memformulasikannya dalam bentuk yang sama sekali baru. Sesungguhnya Ilmuwan muslim Arab dalam kenyataannya sendiri adalah pembuat metodologi penelitian ilmiah yang benar dengan didasarkan pada uji coba. Sesungguhnya kaum muslimin Arab bukan hanya menyelamatkan peradaban bangsa Yunani dari kepunahan, menyusun dan mengklasifikasikannya, kemudian menghadiahkan begitu saja kepada Barat. Sebenarnya pula, kaum muslimin merupakan peletak dasar berbagai macam metodologi uji coba dalam berbagai bidang, seperti fisika, kimia, psikologi, dan matematika. Di samping itu, masih banyak lagi penemuan-penemuan yang tidak terhitung jumlahnya. Namun sayang sekali, semua itu kebanyakan "telah dicuri" dan dinisbahkan kepada orang lain. Ilmuwan muslim Arab telah menyuguhkan 
hadiah yang paling mahal, yakni metodologi penelitian ilmiah yang benar, yang membuka jalan bagi bangsa Barat mengetahu rahasia alam dan menguasai apa yang mereka temukan sekarang ini. ${ }^{20}$

Florence Kajore dalam buku "sejarah fisika" mengatakan, "Sesungguhnya ulama Arab dan kaum muslimin adalah manusia pertama dan orang yang paling baik menggunakan metode penelitian. Metode ini patut dianggap sebagai kebanggaan dari mereka dari berbagai kelebihan yang membanggakan. Mereka adalah manusia pertama yang menemukan manfaat dan betapa pentingnya metode ini dalam ilmu-ilmu pengetahuan alam, terutama Ibnu al-Haytham sebagai pionernya."

AI Sabra dan JP Hogendijk, dalam karyanya, The Enterprise of Science in Islam: New Perspectives, memuji kehebatan Kitab al-Manāzir. Keduanya menganggap Kitab Optik telah melakukan sebuah revolusi di bidang optik dan persepsi visual secara luas.

Kitab al-Manāzir juga mendapat pujian dari banyak sejarawan sains Barat lain. "Alhazen malahan sangat sukses mengembangkan teori yang menjelaskan proses penglihatan oleh sinar terang yang dilanjutkan ke mata dari setiap titik pada obyek yang ia buktikan melalui eksperimen", ungkap DC Lindberg dalam karyanya bertajuk Theories of Vision from al-Kindi to Kepler.

GJ Toomer dalam Review: Ibn al-Haythams Weg zur Physik by Matthias Schramm, mengungkapkan, perpaduan optik geometrik dengan bentuk falsafah fisika yang dikupas dalam Kitab al-Manāzir telah membentuk dasar optik modern. Demikian pula Dr. Mahmoud al-Deek dalam karyanya Ibn al-Haytham: Master of Optics, Mathematics, Physics and Medicine, menuturkan bahwa Ibn alHaytham dalam Buku Optik-nya telah membuktikan perjalanan sinar terang di garis lurus. Selain itu, di buku itu juga diungkapkan mengenai sejumlah percobaan dengan lensa, cermin, pembiasan, dan refleksi.

\section{Pengembangan Optik Geometri}

Albrecht Heeffer dalam karyanya Kepler's Near Discovery of the Sine Law: A Qualitative Computational Model menyatakan, "Ia (al-Haytham) adalah orang pertama yang mengurangi refleksi dan pembelokan sinar cahaya ke komponen

${ }^{20}$ Fauziah, "Ibnu al-Haitsam.” 
vertikal dan horisontal yang mendasar dalam pengembangan optik geometri." Menurutnya, al-Haytham juga menemukan teori yang mirip dengan hukum sinus Snell, yang dikemukakan juga oleh AI Sabra dalam karyanya Theories of Light from Descartes to Newton.

Menurut KB Wolf dalam karyanya "Geometry and dynamics in refracting systems", pemikiran Ibn al-Haytham dalam Buku Optik tak seperti ilmuwan kontemporer. J Wade dan Finger, menegaskan, Ibn al-Haytham sangat dihargai dan dihormati berkat penemuan kamera obscura dan kamera pinhole. Ilmuwan hebat ini juga menulis pembiasan cahaya, terutama pada pembiasan atmospheric, penyebab pagi dan senja sore. ${ }^{21}$

Pemikiran-pemikiran penting yang diungkap oleh Ibn al-Haytham, antara lain tentang proses penglihatan, bagian-bagian mata, catoptrics dan dioptrics, pembiasan cahaya, cermin, dan lensa. Salah satu konsep dasar optika yang berhasil diungkap oleh Ibn al-Haytham adalah tentang proses penglihatan. Penjelasan ilmiah tentang proses penglihatan yang dikemukakan Ibn alHaytham adalah bahwa suatu objek bisa tampak atau terlihat oleh mata karena adanya sinar-sinar yang dipancarkan dari objek tersebut ke mata. Sinar-sinar tersebut difokuskan atau dibiaskan pada retina, kemudian disalurkan ke otak melalui saraf optik, sehingga terbentuklah gambaran objek yang dilihat tersebut.

Dalam optika yang berhubungan dengan mata, Ibn al-Haytham adalah orang pertama yang memberi gambaran secara akurat tentang bagian-bagian mata. Istilah-istilah pada bagian-bagian mata yang diperkenalkan Ibn alHaytham, antara lain retina, konjungtiva, iris, lensa, kornea, humour viteous, dan humour aqueous. Dia juga menjelaskan peranan masing-masing terhadap penglihatan manusia. Hasil penelitian al-Haytham itu lalu dikembangkan Ibnu Firnas, di Spanyol dengan membuat kaca mata.

Penelitian Ibn al-Haytham dalam catoptrics (bahasan tentang optika permukaan pemantul) dikhususkan menyelidiki cermin sferis, paraboloida serta aberasi sferis. Dalam dioptrics (bahasan tentang optika elemen pembias), Ibn alHaytham memberi hasil pengamatan yang penting tentang perbandingan antara sudut sinar datang dan sudut sinar bias tidaklah tetap, serta pengamatannya terhadap daya pembesaran lensa. Tulisan Ibn al- Haytham tentang pembesaran

21Fauziah, "Ibnu al-Haitsam.” 
lensa kemudian digunakan sebagai rujukan untuk mengoreksi gangguan pada mata.

\section{Cara Kerja Pengamatan Ilmu Ibn al-Haytham}

Ibnu al-Haytham melakukan suatu pengamatan yang seksama terhadap lintasan cahaya yang melalui berbagai medium dan menemukan hukum-hukum pembiasan cahaya. Ibn al-Haytham menjadi orang pertama yang mengungkapkan suatu hukum yang berhubungan dengan sifat-sifat cahaya, dan sekarang ini dikenal dengan Hukum Snellius, yakni 600 tahun sebelum Snell menemukan hukumnya itu. Ibn al-Haytham jugalah yang pertama melakukan percobaan penguraian (dispersi) cahaya menjadi warna-warna tertentu.

Lebih lanjut mengenai penemuan Ibn al-Haytham tentang optik yang telah dikembangkan oleh para ilmuwan pada generasi di masa kini menjadi benda yang sangat populer dan penting bagi pencatatan sejarah, yakni kamera. Kata kamera yang digunakan saat ini berasal dari bahasa Arab, yakni qamara. Jauh sebelum masyarakat Barat menemukan kamera, prinsip-prinsip dasar pembuatan kamera telah dicetuskan seorang sarjana Arab, sekitar 1000 tahun silam. Peletak prinsip kerja kamera itu adalah seorang saintis legendaris Arab bernama Ibn al-Haytham. Pada akhir abad ke-10 M, al-Haytham berhasil menemukan sebuah kamera obscura.

Penemuan yang sangat inspiratif itu berhasil dilakukan al-Haytsan bersama Kamaluddin al-Farisi. Keduanya berhasil meneliti dan merekam fenomena kamera obscura. Penemuan itu berawal ketika keduanya mempelajari gerhana matahari. Untuk mempelajari fenomena gerhana, al-Haytham membuat lubang kecil pada dinding yang memungkinkan citra matahari semi nyata, diproyeksikan melalui permukaan datar. ${ }^{22}$

\section{Pemikiran Jabir ibn Hayyan}

Beliau merupakan seorang ilmuwan dan filosof terkemuka yang memiliki nama lengkap Abu Musa Jabir ibn Hayyan al-Azdi. Kalangan Barat mengenal dengan nama Geber. Beliau lahir di Thus Khurasan, Iran (Persia), pada tahun $721 \mathrm{M}$ atau sekitar abad ke-8. Jabir adalah seorang yang berketurunan Arab,

22Zulfan Afdhila, Biografi Ibu Haytham Bapak Optik Pencipta Kamera, dalam http://www.zulfanafdhilla.com/2014/07/alHazen.html, diakses pada Selasa, 01 Juli 2014. 
namun ada juga yang mengatakan bahwa ia adalah orang Persia. Ayahnya bernama Hayyan al-Azdi berasal dari suku Arab Azd adalah seorang yang ahli di bidang farmasi dari kabilah Yaman yang besar yaitu kabilah Azad, dan sebagian besar dari mereka berhijrah ke Kufah setelah rubuhnya Bendungan Ma'rib. Disamping seorang yang ahli di bidang farmasi, ayahnya juga merupakan seorang yang mendukung Dinsati Abbasiyah dan ikut serta membantu meruntuhkan Dinasti Umayyah. Pada masa kekuasaan Bani Umayyah, ia hijrah dari Yaman ke Kufah yang merupakan salah satu kota pusat pergerakan syi'ah di Iraq. Ketika ayahnya sedang melakukan pemberontakan, ia tertangkap oleh pasukan Dinasti Umayyah di Khurasan, kemudian ia dieksekusi dan dihukum mati. Setelah ayahnya meniggal, Jabir dan keluarganya kembali ke Yaman dan ia mulai mempelajari al-Qur'an dan berbagai ilmu lainnya dari seorang ilmuwan yang bernama Harbi al-Himyari.

Jabir kembali ke Kufah setelah Abbasiyah berhasil menumbangkan Umayyah dan mulai merintis karirnya di bidang kimia. Ketertarikannya dalam bidang ini yang membuatnya terus mendalaminya sehingga menjadi seorang ahli dalam kimia. Ada yang mengatakan, ketertarikan kepada kimia dikarenakan oleh profesi ayahnya sebagai seorang peracik obat. Jabir ibn Hayyan hidup pada masa dua dinasti, yakni akhir kekhalifahan Umayyah dan awal kekhalifahan Abbasiyah. $^{23}$

Jabir kemudian mempelajari ilmu kedokteran pada masa Kekhalifahan Abbasiyah di bawah pimpinan Harun al-Rashīd dari seorang guru yang bernama Barmaki Vizier. Jabir pun terus bekerja dan bereksperimen dalam bidang kimia dengan tekun di sebuah laboratorium dekat Bawaddah di Damaskus dengan ciri khas eksperimen-eksperimennya yang dilakukan secara kuantitatif, bahkan instrumen-instrumen yang digunakan untuk eksperimennya dibuat sendiri dari bahan logam, tumbuhan dan hewani.

Di laboratoriumnya itulah Jabir berhasil menemukan berbagai penemuan besar yang sangat bermanfaat sampai saat ini, bahkan di laboratorium itu pula telah ditemukan berbagai peralatan kimia miliknya, dan setelah sempat berkarir di Damaskus, Jabir dikatakan kembali ke Kufah setelah terjadi tragedi Baramikah. Sekembalinya ke Kufah tak banyak lagi yang mengetahui tentang

23Philip K. Hitti, History of The Arabs, 364-368. 
keberadaannya, namun dua abad setelah kematiannya barulah ditemukan laboratoriumnya seperti yang telah disebutkan tadi di atas. Di dalamnya didapati peralatan kimianya yang hingga kini masih mempesona, dan sebatang emas yang cukup berat.

Kontribusi terbesar Jabir adalah dalam bidang kimia. Keahliannya ini didapatnya dengan berguru pada Barmaki Vizier, pada masa pemerintahan Harun al-Rashid di Baghdad. Ia mengembangkan teknik eksperimentasi sistematis di dalam penelitian kimia, sehingga setiap eksperimen dapat direproduksi kembali. Jabir menekankan bahwa kuantitas zat berhubungan dengan reaksi kimia yang terjadi, sehingga dapat dianggap Jabir telah merintis ditemukannya hukum perbandingan tetap. Kontribusi lainnya antara lain dalam penyempurnaan proses kristalisasi, distilasi, kalsinasi, sublimasi dan penguapan serta pengembangan instrumen untuk melakukan proses-proses tersebut.

Sebagaimana halnya ilmuwan muslim abad pertengahan, Jabir ibn Hayyan tidak hanya mampu mendalami satu bidang ilmu tertentu, tetapi mereka juga mampu menguasai bidang keilmuwan lainnya dan sangat beragam. Selain ahli dalam bidang ilmu kimia, beliau juga ahli dalam ilmu yang lain seperti kedokteran, filsafat dan fisika. Hanya saja dari sekian banyak ilmu yang digelutinya, tampaknya ilmu kimia lebih melekat dan menonjol pada beliau. Karya-karya beliau banyak diterjemahkan ke dalam berbagai bahasa, dan kemudian diserap oleh ilmu kimia modern. Eropa kemudian mulai mengenal istilah-istilah teknik seperti realiger (sulfit merah dari arsenik), tutia (seng oksida), alkali, antimonia, alembic, dan aludel. Demikian juga salamoniak (sejenis substansi baru kimia) telah diperkenalkan oleh Jabir ibn Hayyan yang sebelumnya tidak perrnah dikenal oleh orang-orang Yunani. ${ }^{24}$

Beberapa penemuan Jabir Ibn Hayyan diantaranya adalah: asam klorida, asam nitrat, asam sitrat, asam asetat, tehnik distilasi dan tehnik kristalisasi. Dia juga yang menemukan larutan aqua regia (dengan menggabungkan asam klorida dan asam nitrat) untuk melarutkan emas. Jabir Ibn Hayyan mampu mengaplikasikan pengetahuannya di bidang kimia ke dalam proses pembuatan besi dan logam lainnya, serta pencegahan karat. Dia jugalah yang pertama mengaplikasikan penggunaan mangan dioksida pada pembuatan gelas kaca.

${ }^{24}$ Edy Chandra, "Religiusitas dalam Pendidikan Kimia: Pemikiran Pendidikan Kimiawan Klasik Jabir bin Hayyan," Jurnal Scientiae Educatia 1 No. 1, (April 2012), 6-7. Lihat juga Imelda Fajriati, "Perkembangan Ilmu Kimia di Dunia Muslim", Jurnal Sosio-Religia 9 No. 3 (Mei 2010), 10-60. 
Jabir Ibn Hayyan juga pertama kali mencatat tentang pemanasan wine akan menimbulkan gas yang mudah terbakar. Hal inilah yang kemudian memberikan jalan bagi Al-Razi untuk menemukan etanol.

Jika kita mengetahui kelompok metal dan non-metal dalam penggolongan kelompok senyawa, maka Jabirlah yang pertamakali melakukannya. Dia mengajukan tiga kelompok senyawa, yaitu: 1) "Spirits" yang menguap ketika dipanaskan, seperti camphor, arsen dan amonium klorida. 2) "Metals" seperti emas, perak, timbal, tembaga dan besi. ${ }^{25}$ 3) "Stones" yang dapat dikonversi menjadi bentuk serbuk.

Secara kontinu Jabir mengembangkan penelitiannya di bidang kimia hingga mampu memiliki karya dalam bidang kimia mencapai 500 studi kimia, namun hanya sebagian saja yang berhasil ditemukan sampai pada zaman Renaisance. Di antara bukunya yang terkenal diantaranya adalah: 1) al-Hikmah al-Falsafiyah yang diterjemahkan ke dalam bahasa Latin dan berjudul Summa Perfecdonis, dan tahun 1678, ilmuwan Inggris lainnya, Richard Russel, mengalihbahasakan karya Jabir ini dengan judul Summa of Perfection, 2) Kitāb al-Raḥmah, 3) Kitab alTajmi, 4) al-Zilaq al-Sharqi, 5) Book of The Kingdom, 6) Book of Eastern Mercury, 7) Book of Balance (ketiganya diterjemahkan oleh Berthelot), 8) al-Khawash, 9) Sifat al-Kaun (kosmologi), 10) al-Hikmah al-Mashunah, 11) al-Ṭabi'ah, 12) Shunduq al-hikmah (Rongga Dada Kearifan), merupakan sebuah manuskrip, 13) al-Lahut, 14) al-Ṭabi'ah al-Fa'ilah al-ulā al-Mutaḥarrikah, 15) Kitāb al-Sumūm, 16) Asrār al-Hikmah, 17) Al-Sir al-Maknun, 18) Al-Takhlish, 19) Al-Ihraq, 20) AlIbdah, 21) Shubh al-Nufus, 22) al-Sir al-Maktum, 23) al-Ijaz, 24) al-Juf al-Aswār, 25) Nihāyat al-Itqān, 26) Istiqșa'at al-Mu'allim, 27) al-Kimia al-Jabiriyyah, 28) Kitāb al-Sab'in, 29) al-Zuhrā, diterjemahkan menjadi Book of Venus, 30) Kitab alAhjār yang diterjemahkan menjadi Book of Stones, 31) al-Kimya, diterjemahkan dan diterbitkan oleh ilmuwan Inggris, Robert Chester pada 1444, dengan judul The Book of the Composition of Alchemy, dan 32) Mukhtār Rasāìil.

\section{Kimia Islam sebagai Embrio Ilmu Kimia Modern}

Temuan empirik menjadi dasar sains-sains modern, termasuk ilmu kimia. Berabad-abad sebelum muncul peradaban Islam, premis-premis dasar kimia telah berdiri dengan kokoh seiring dengan perkembangan filsafat alam skolastik

\footnotetext{
${ }^{25}$ Lihat dalam Mulyadhi Kartanegara, Mozaik Khazanah Islam (Bunga Rampai dari Chicago), (Jakarta: Paramadina, 2000), 18.
} 
yang membentuknya. ${ }^{26}$ Memasuki dunia kimia Islam, asumsi-asumsi dasar tersebut mengalami penyesuaian serta terjadi pertautan antara tema-tema kimiawi, spiritual, dan mistis. Para ahli kimia muslim berusaha mengungkap fenomena alam yang kadangkala bagi sebagian orang masih misteri dan sulit dimengerti menjadi sesuatu yang dapat dipelajari. Tidak jarang pula, ahli kimia muslim seringkali dianggap sebagai ahli pseudo sains.

Lebih jauh, perhatian ahli kimia muslim diarahkan pada kemampuan di seputar berubahnya logam biasa menjadi logam mulia (emas) atau disebut peristiwa transmutasi. Peristiwa ini menjadi pekerjaan umum dalam ilmu kimia hingga disusun tabel dan diagram kosmologi dari ilmuwan besar Jabir ibn Hayyan. Diagram ini menjadi populer karena mencerminkan letak unsur-unsur serta seluruh benda mati dan hidup ke dalam kerangka rasi yang dinamis. Transmutasi logam biasa menjadi emas melambangkan upaya menuju kesempurnaan atau ketinggian eksistensi. Ahli kimia klasik termasuk ahli kimia muslim meyakini bahwa seluruh alam semesta sedang bergerak menuju keadaan sempurna; dan emas, karena tak pernah rusak, dianggap zat yang paling sempurna. Dengan diubahnya logam biasa menjadi emas, ahli kimia sebenarnya mencoba membantu alam semesta menjaga kelestariannya. Maka, menjadi logis jika dengan memahami rahasia ketakberubahan emas akan ditemukan kunci untuk menjaga eksistensi dan kelestarian materi yang ada di alam semesta. Francis Bacon (1561-1626 M).

\section{Peran dan Kontribusi Kimia Islam bagi Peradaban}

Tokoh-tokoh yang memberi karakteristik kimia Islam adalah Jabir ibn Hayyan, ar-Razi ${ }^{27}$ dan Izz al-Din al-Jaldaki. ${ }^{28}$ G. Le Bon menyebutkan bahwa banyak bahan kimia yang sebelum Geber (Jabir) tidak dikenal, berkat jasanya menjadi dikenal. Beberapa zat yang ditemukan oleh ahli kimia muslim yang sampai saat ini masih terus digunakan dan bahkan telah dikembangakan menjadi senyawa penting antara lain:29

\footnotetext{
${ }^{26}$ Howard R. Turner, Science in Medieval Islam: An Illustrated Introduction, alih bahasa Andri Zulfahmi, (Austin: University of Texas Press, 1997), 201.

${ }^{27}$ Mehdi Nakosteen, Kontribusi Islam atas Dunia Intelektual Barat: Deskripsi Analisis Abad Keemasan Islam (Surabaya: Risalah Gusti, 2003), 234.

${ }^{28}$ Isma il Raji al-Faruqi, Atlas Budaya Islam: Menjelajah Khazanah Peradaban Gemilang, (Jakarta: Mizan, 1998), 362

${ }^{29}$ Budi Yuwono, Ilmuwan Islam Pelopor Sains Modern (Jakarta: Pustaka Qalami, 2005), 85.
} 


\section{a. Asam Sulfat $\left(\mathrm{H}_{2} \mathrm{SO}_{4}\right)$}

Asam sulfat mulai dikenal oleh Jabir ibn Hayyan ketika dia berhasil menemukan unsur belerang serta mereaksikan dengan merkuri dan air. Oleh alRazi, sifat bahan dasar asam sulfat, yaitu unsur belerang diklasifikasikan lebih sistematis dengan membedakan antara yang alami ditemukan di alam dengan mineral yang berhasil dibuat di laboratorium berdasarkan reaksi dekomposisinya.

Temuan zat berharga oleh ilmuwan kimia muslim ini pada akhirnya mempengaruhi perkembangan sains dan teknologi pada era sesudahnya. Kunci revolusi industri di Eropa dan Amerika Serikat ternyata hanya asam sulfat. Senyawa dari ikatan satu atom belerang dengan dua atom hidrogen dan empat atom oksigen atau $\mathrm{H}_{2} \mathrm{SO}_{4}$ ini, adalah bahan dasar untuk pembuatan berbagai produk modern.

Klaus Blum mengatakan bahwa seluruh peradaban manusia dalam 100 tahun terakhir sangat dipengaruhi senyawa dasar kimia semacam itu. Tanpa senyawa dasar seperti asam sulfat, umat manusia tidak dapat membuat obatobatan, peralatan rumah tangga sehari-hari, hingga produksi sabun, pupuk, serat nilon, kertas, seluloid dan plexiglas serta untuk perlengkapan mobil seperti air aki. Pemanfaatan yang meluas dari asam sulfat dan turunannya sudah tidak diragukan lagi. Mengacu pada kutipan di atas, salah satu contoh pengolahan kayu menjadi pulp kayu sebagai bahan dasar kertas dan karton adalah menggunakan asam sulfat. ${ }^{30}$

\section{b. Asam Nitrat $\left(\mathrm{HNO}_{3}\right)$}

Seperti halnya asam sulfat, asam nitrat yang berbahan dasar nitrogen juga senyawa penting yang telah dimanfaatkan secara besar-besaran pada masa sekarang. Oleh Jabir ibn Hayyan, senyawa ini digunakan untuk memurnikan tawas dan garam, sehingga dari proses penyulingan tersebut akan dihasilkan beberapa mineral anorganik seperti kalium nitrat $\left(\mathrm{K}^{\left.\left(\mathrm{NO}_{3}\right)\right)}\right.$ dan natrium klorida ( $\mathrm{NaCl}$ ).

Pemanfaatan asam nitrat di era kimia modern semakin luas, diantaranya selain sebagai bahan dasar super pelarut (aqua regia), asam nitrat adalah

${ }^{30}$ Nachtrib, Prinsip-prinsip Kimia Modern, alih bahasa Ahmadi Suminar (Jakarta: Erlangga, 2005), 228. 
penyusun utama dari bahan peledak TNT (2, 4, 6 trinitrotoluena) yang tersubstitusi dari senyawa benzena (bahan bakar minyak, bensin). Selain dalam bentuk TNT, asam nitrat juga berikatan dengan amonium membentuk amonium nitrat dan berfungsi sebagai pupuk pertanian, tetapi senyawa ini dapat sebagai detonator dan eksplosif jika berkontak dengan senyawa asing seperti klorida.

\section{c. Aqua Regia}

Bahan ini adalah pelarut yang bersifat amat kuat dalam melarutkan bahan melebihi asam-asam lain yang juga dikenal dapat melarutkan bahan seperti asam klorida $(\mathrm{HCl})$, asam sulfat $\left(\mathrm{H}_{2} \mathrm{SO}_{4}\right)$, asam nitrat $\left(\mathrm{HNO}_{3}\right)$. Pelarut ini dibuat dengan mencampurkan dua jenis pelarut seperti potasium nitrat dan asam klorida. Para ilmuwan masa sekarang amat terbantu dengan temuan pelarut ini. Aqua regia akan dapat melarutkan material khususnya logam murni, termasuk emas dan perak, serta alloy dan bahan polimerik yang solid dan kaku.

Pelarut di atas oleh beberapa kimiawan muslim biasanya digunakan untuk kepentingan kerajaan seperti menempa logam untuk pembuatan peralatan militer, serta perlengkapan istana raja yang dimodifikasi dari bahan logam, emas, platina dan perak. Menurut E. J Holmyard, ${ }^{31}$ Jabir ibn Hayyan juga berhasil mengidentifikasi serta mempelajari sifat-sifat dari tujuh macam logam, yakni: emas $(\mathrm{Au})$, perak $(\mathrm{Ag})$, timbal $(\mathrm{Pb})$, timah $(\mathrm{Sn})$, tembaga $(\mathrm{Cu})$, merkuri $(\mathrm{Hg})$ dan besi (Fe).

\section{d. Besi (Fe)}

Temuan logam besi (Fe) oleh ahli kimia muslim abad ke-8 $\mathrm{M}$ amat penting bagi peradaban sesudahnya. Sebagai unsur alam yang selalu tersedia dalam bentuk campurannya, ilmuwan muslim mengembangkan metode pemurnian dengan cara konvensional, di antaranya dengan melelehkan campuran besi di alam melalui pemanasan suhu tinggi dalam tanur, sehingga akan didapatkan globula (butiran yang tersebar dalam kerak semi-cair). Produk yang dihasilkan yaitu besi tempa. ${ }^{32}$

Sebagai salah satu logam yang keberadaannya cukup melimpah di bumi, besi (Fe) seringkali dijumpai di alam dalam bentuk bijih, yaitu mineral yang

31E. J Holmyard, Alchemy (Inggris: Penguin Baltimore, 1957), 80.

${ }^{32}$ Holmyard, Alchemy, 208. 
bergabung dengan unsur lain seperti oksigen dan sulfur, adapun besi di alam lebih banyak dalam bentuk mineral hematit $\left(\mathrm{Fe}_{2} \mathrm{O}_{3}\right)$, magnetit $\left(\mathrm{Fe}_{3} \mathrm{O}_{4}\right)$ dan siderit $\left(\mathrm{FeCo}_{3}\right)^{33}$

\section{e. Alkohol}

Identifikasi senyawa alkohol (etanol) telah dimulai sejak masa Jabir ibn Hayyan. Bahan senyawa ini kerapkali dimanfaatkan sebagai bahan peledak untuk kepentingan kerajaan yang menggunakan campuran anggur mendidih dengan dimasukkan dalam botol. Beberapa sifat lain alkohol adalah dapat memabukkan bagi siapa saja yang meminumnya. Oleh kalangan kerajaan, dibuatlah berbagai ramuan untuk minuman kerabat raja dan mayarakat golongan tertentu. Alkohol dan turunannya telah banyak digunakan dan banyak hasil temuan dan identifikasi zat serta beberapa metode analisis yang dihasilkan oleh ahli kimia Islam yang telah dinikmati dan dikembangkan oleh ilmuwan dan masyarakat pada masa sesudahnya.

\section{E. Kesimpulan}

Metode berpikir yang diramu oleh para pemikir muslim seperti Ibn Rushd, Ibn al-Haytham, Jabir ibn Hayyan dan lain-lain yang dikemas dalam suatu cara pandang yang lebih elegan dengan cara membongkar metode berpikir tekstualis dan doktrinal, yang selanjutnya menghadirkan cara berpikir kontekstualis merupakan daya tarik tersendiri bagi metode berpikir mereka yang mendapatkan tempat di hati para pemikir belakangan untuk mengikuti pola pikirnya. Cara pandang yang ditawarkan telah mampu mengalihkan pola pikir eksklusivisme menuju pola pikir inklusivisme yang dikemas secara rasional dan eksperimental. Dengan cara pandang seperti ini, cara pandang dan metode berpikir yang dikembangkan pada masa berikutnya sudah lebih rasional dan sistematis ketimbang model pemikiran yang berkembang sebelumnya.

Apa yang dikembangkan oleh mereka berpengaruh sangat besar pada perkembangan sains modern dan merupakan angin segar bagi perkembangan sains dan teknologi di era kontemporer seperti sekarang ini. Banyak pemikir Barat yang mengadopsi pola pikir mereka, sehingga tidak sedikit dari mereka

33Holmyard, Alchemy, 208. 
yang berkiblat pola pemikirannya kepada para saintis muslim. Apa yang disuguhkan dan dipersembahkan oleh para pemikir muslim telah mampu menyulap sains modern sebagaimana yang berkembang di dunia sekarang ini, baik di Barat maupun di Timur.[]

\section{DAFTAR PUSTAKA}

Abdurrahman. Pengaruh Arab dalam Bentuk Pemikiran Eropa (Suatu Catatan Kebangkitan Islam), terj. Mohammad Ma'ruf Misbah. Semarang: CV. Wicaksana, t.th.

Afdhila, Zulfan. "Biografi Ibu Haytham Bapak Optik Pencipta Kamera," dalam http://www.zulfanafdhilla.com/2014/07/alHazen.html, diakses pada Selasa, 01 Juli 2014

Ahmad, Jamil. Seratus Muslim Terkemuka, Jakarta: Pustaka Firdaus, t.th.

Ahmad, Zainal Abidin. Riwayat Hidup Ibn Rusyd (Averroes): Filosof Islam Terbesar di Barat. Jakarta: Bulan Bintang, 1975.

Arif, Syamsuddin. "Ibnu Rusyd dan Kemajuan Barat." Islamia: Jurnal Pemikiran Islam Republika, Kamis, 20 Januari 2011.

Chandra, Edy. "Religiusitas dalam Pendidikan Kimia: Pemikiran Pendidikan Kimiawan Klasik Jabir ibn Hayyan." Jurnal Scientiae Educatia 1, no. 1 (April 2012).

Donaldzen, D.L. Studies in Muslim Ethics. London: t.p., 1953.

Fajriati, Imelda. "Perkembangan Ilmu Kimia di Dunia Muslim." Jurnal Sosio-Religia 9, no. 3 (Mei 2010).

Fakhry, Madjid. A Histoty of Islamic Philosophy. New York and London: Columbia University Press, and Longman, 1983.

al-Faruqi, Isma il Raji. Atlas Budaya Islam: Menjelajah Khazanah Peradaban Gemilang. Jakarta: Mizan, 1998.

Fauziah. "Rahasia Dibalik Penemuan Kacamata". http://www.republika.co.id/ berita/ensiklopedia-islam/khazanah/09/04/30/47404-rahasia-di-balikpenemuan kacamata.html, diakses pada 26 Mei 2012. 
Fauziah. "Ibnu al-Haitsam: Sejarah Penemuan Optik dan Pengaruhnya terhadap Sains Barat Modern". http://sejarah.kompasiana.com/2012/12/29/ ibnu-al-haitsam-sejarah-penemuan-optik-dan-pengaruhnya-terhadapsains-barat-modern-html\#_ftn19, diakses pada 14 Juni 2014.

Hitti, Philip K. History of The Arabs. London: Macmillan, 1970.

Holmyard, E. J. Alchemy. Inggris: Penguin Baltimore, 1957.

Ibn Rushd, "Faṣl al-Maqal fi mā bayna al-Hikmah wa '-Shari'ah" dalam Kitab Falsafah Ibn Rushd.

Kartanegara, Mulyadhi. Mozaik Khazanah Islam (Bunga Rampai dari Chicago). Jakarta: Paramadina, 2000.

Leaman, Oliver. An Introduntion to Medieval Islamic Philosophy. Cambridge: Cambridge University Press, 1985.

-——. Averroes and his Philosophy. Oxford: Clarendon Press, 1988.

Mahdi, Muhsin. dalam M.E. Marmura (ed.) Islamic Teology and Philosophy. Albany: State University of New York Press, 1984.

Meirizka, Syarach.Sang Jenius Optik “The True Scientist” Ibnu Al-Haytham (email version), Scientia Experia Publisher, 2011.

Mohaini, Mohamed. Matematikawan Muslim Terkemuka. Jakarta: Salemba Teknika, 2004.

Mūsā, Muhammad Yūsuf, Falsafat al-Akhlāq al-Islām. Kairo: Mu’assasah al-Khārijī al-Arabiyyah, 1963.

_—_. Bain al-Dīn wa al-Falsafah fi Ra'yi Ibn Rushd wa Falasifah fi 'Ashr al-Wāsiț. Mesir: Dār al-Ma'ārif, t.th.

_—_. al-Nasy'at al-'Aqliyyah fi Falsafah Ibn Rushd. Mesir: Dār al-Ma'ārif, t.th.

Nachtrib. Prinsip-prinsip Kimia Modern, terj. Ahmadi Suminar. Jakarta: Erlangga, 2005.

Nakosteen, Mehdi. Kontribusi Islam atas Dunia Intelektual Barat: Deskripsi Analisis Abad Keemasan Islam. Surabaya: Risalah Gusti, 2003.

Poedjawijatna. Pembimbing ke Arah Filsafat. Jakarta: Rineha Cipta, 1994. 
Qāsim, Maḥmūd. Falsafah Ibn Rushd wa Atharuhā fi al-Tafkīr al-Gharbī. Kairo: Jāmi'ah Umm al-Qarmān al-Islāmiyyah, 1967.

Romlah, Siti. "Sains dan Teknologi dalam al-Qur'an (Fenomena Makrokosmos dan Mikrokosmos)." Jurnal Studi Islam: Pancawacana 11, no. 2, (Desember 2016).

Shubhī, Ahmad Muhammad. al-Falsafat al-Akhlāqiyyah fi al-Fikr al-Islāmī. Mesir: Dār al-Ma’āirif, 1969.

Tafsir, Ahmad, Filsafat Umum: Akal dan Hati Sejak Thales sampai James. Bandung: PT. Remaja Rosdakarya, 1990.

Tawfiqq, Tawīl. Falsafat al-Akhlāq: Nash'atuh wa Tatawwuruh. Kairo: Nahdhat al'Arabiyyah, 1979.

Turner, Howard R. Science in Medieval Islam: An Illustrated Introduction, Austin: University of Texas Press, 1997.

Yuwono, Budi. Ilmuwan Islam Pelopor Sains Modern. Jakarta: Pustaka Qalami, 2005. 
